\title{
Prayer Book Catechism: Past its sell-by date?
}

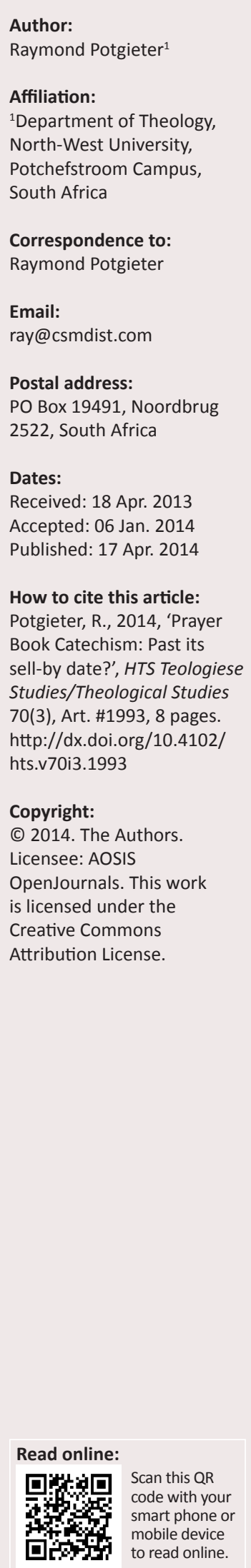

The Book of Common Prayer (BCP) is the first introduction to Anglican belief and liturgy for many. More specifically, the Book of Common Prayer of 1662 contains the traditional catechism of the Church of England, enjoining catechumens to receive training and instruction in basic doctrines and Christian living. This takes place in the contexts of the liturgy and the more comprehensive doctrinal statements of the 39 Articles of Religion. Anglican religion traditionally allowed its members to verbalise their faith in both ritual and confession, thus serving the church and not so much life in the world. A revisit of the intentions of the catechism within its historical and prayer book contexts will show that it essentially expresses lasting truths of the Christian faith. In a world increasingly divorced from particular Christian expressions, the Anglican Church needs to rethink its particular use of the catechism for its continued relevance in meeting the questions and challenges Anglicans face daily.

\section{Introduction}

\section{Duffy (2005) has indicated:}

Believers and unbelievers were agreed that whatever the true claims of Christianity, the Reformation was a vital stage along the road to modernity, the cleansing of the English psyche from priestcraft, ignorance and superstition. (p. xiii)

The Anglican Prayer Book catechism (PBC) is a product of the English Reformation. But what about the continued impact 500 years later? Gregory's genealogical analysis of Western modernity concludes that the consequence of the Reformation, in tandem with Enlightenment propositions and Medieval Christendom, is its evident bankruptcy. Science is seen to be in the process of falsifying religion with its monolithic claims as the source of all truth, with God relegated to satisfying personal needs (Gregory 2012:365, 367). Not least, was the hermeneutical emphasis upon the 'wide range of incompatible truth claims that a shared commitment to sola scriptura produced' (Gregory 2012:95). This did not allow for individual interpretations of reality and concluded with today's dissension of what the church is to view as the true understanding of reality. Clearly, these comments must reflect upon the continued relevance of the historical statements of the Christian Church and their continued relevance for the present.

It is within this contemporary context that the Anglican Catechism ought to be viewed because it is one of the significant and enduring products of the English Reformation. For almost 400 hundred years it was included in the Book of Common Prayer (BCP), more particularly the 1662 version, and accompanied and served worshippers, whether in England, elsewhere in the Commonwealth or in missionary situations (Kraus 2006:541). Significant as a tool of the Church of England from its origin and historical continuance, its continued relevance to third millennium believers must be questioned. Or has the catechism reached its sell-by date? In this article, some suggestions as to how to recapture the significance of the catechism will be made.

\section{The Catechism within the context of the Prayer Book: A historical overview}

According to Whalon (2006):

As Christians, Anglicans are 'people of the Book', in the Qu'ran's phrase; but as Anglicans they are 'people of two books'. While the scriptures are the ultimate rule of faith for Anglicans, their faith takes its form from the collective and individual use of the PB which interprets the Bible. (p. 551)

This puts things into historical and chronological perspective for anyone coming to the Anglican faith and its catechism. In fact the Prayer Book (PB) is, as it were, a library of books; prior to its publication each formed a separate book, now compiled into a single publication (Eland 1896:3). A brief look at the dynamics at work during the early English Reformation will allow for some insight into the crucible from which it emerged and was shaped. But it will also be shown that the 
catechism cannot be viewed as a single document, divorced from the PB. That, in this writer's opinion, is its genius and unique to the English Reformation.

Birthed in the English Reformation, the Church of England united the continental doctrines of the Reformation into a particular Anglican form, developing its distinctive style of worship. Unity amongst its communion of believers centred in the uniform text of the BCP 1662, which in turn was supported by various Acts of Uniformity ${ }^{1}$. It provided an alternative to Catholic worship practices of Rome and its interpretations depended on an understanding of the Bible as particularly understood by the major reformers and its own theologians. Regard for the BCP is expressed by Liverpool (1912:vii) as the church people's 'great Book of Devotion, one of the precious results of the English Reformation', a book 'the Reformers were ready to sacrifice their lives in its defence' (Lathbury 1859:25). A more contemporary evaluation of the period however, states simply that it was the book of choice furthering the Protestant Reformation in England (Hefling 2006:3). The aforementioned quote clearly included the catechism, whilst the latter could apply, although in some prayer books it is now omitted. This will be discussed in what follows.

Heresy was nothing new to the English church of the 1500's and by 1535, with Cromwell's support, criticism of Roman Catholic devotional practices and the doctrines in support of them were openly questioned and opposed (Duffy 2005:379, 383). In due course the more visible expression of these doctrines as promoted by monasteries, in support of shrines, pilgrimages and images all came under attack. Radical (read reformed) preaching had the support of Thomas Cromwell (1485-1540) and church leaders such as Thomas Cranmer (1489-1556) and Hugh Latimer (1487-1555) (Duffy 2005:388). Despite his attack on the papacy, Henry VIII (1491-1547) never quite shifted from much of the traditional Roman Catholic forms of religion (Duffy 2005:448). In reality, traditional religion, as practiced before the Reformation took effect in England, was still strongly in evidence in communities such as abbeys and in the use of relics and traditional ceremonies (Duffy 2005:424). Henry's Act of Six Articles 1539, popularly known as 'the whip with six strings' (Cross \& Livingstone 1974:1281), was the evangelical turning point in that according to Duffy (2005:424), it forced a choice of promoting Catholicism or Protestantism². Pamphlets in circulation proposing various lay religious catechetical instructions were addressed by the King's Primer of 1545 and settled many disjointed religious opinions. As a result the 'foundations were slowly but decisively shifting' (Duffy 2005:447). Changes in the reign of the child-king ${ }^{3}$ Edward VI (1537-1553) were cautiously advanced by Archbishop

1.These acts $(1549,1552,1559,1662,1663)$ served to establish the peculiar reformed Anglican distinctions of the Church of England, not allowing any confusion with another religious body.

2.Distinctly Roman Catholic, it led to Cranmer sending his wife to Germany and Shaxton and Latimer resigning their sees. History testifies that this extreme caution proved to be unnecessary, because the requirements of the Articles were generally ignored by authorities and not widely enforced.

3. Hall (1993:31) refers to the 'boy King' and 'the godly prince'.
Cranmer, so as not to be seen as the manipulation of the king ${ }^{4}$. At his request, Bucer (1491-1551) $)^{5}$ and Peter Martyr Vermigli (1499-1562) promoted the 'new theology' (read Lutheranism and Calvinism) at Oxford and Cambridge. Even Calvin is said to have offered his assistance (Luckock 1882:57) ${ }^{6}$. Cranmer prepared the 42 Articles of doctrine $(1553)^{7}$, a set of homilies and a catechism for parishes without ministers (Jeanes 2006:29). With the publication of the PB of 1549 and its revised version in 1552, religious doctrine, practice in rite and ceremony were addressed simultaneously. Here was 'the centrepiece of the Reformation in England' (Jeanes 2006:29). Interestingly enough, this differed markedly from the continental reformation, which found its jewels in Calvin's Institutes, Luther's Small Catechism and so on.

\section{Some key features of the Anglican Catechism}

\section{The context of liturgy}

One of the key differences from most other catechisms of the Reformation, both continental and English, was that the Anglican Catechism was found within the context of a $\mathrm{PB}$, in the immediate context of its worship liturgy. This served to shape the expression of Anglican reformational Christianity for generations to come. Continental catechisms, both Protestant and Catholic, were seen as statements to stand on their own and appropriated by the wider and more diverse Christian communities ${ }^{8}$. They often served to identify with particular church communities; such as those who for instance, hold to a presbyterial form of government, such as the Westminster Confession (Heron 1986:1); whereas the Anglican Catechism is part and parcel of the PB. Anglican Church identity is not simply found upon the catechism, nor its Articles of Faith, but upon the whole of the package comprising the $\mathrm{PB}^{9}$.

\section{Allegiance to the reigning sovereign}

At the level of the local parish in 16th century England, change as a result of Protestant influence was not that evident (Duffy 2005:481). Historically, the populace by and large adapted to the religious transformations brought about by their royal sovereigns, who were regarded as the instruments of God. In due course they adapted to Protestantism under Henry VIII, Roman Catholicism under Mary (1516-1558), and finally reverted to Protestantism again under Elizabeth I

4.With the death of Thomas Cromwell, who served as Viceregent from 1535-1540 juggling the affairs of church and state politics, Cranmer was forced to step into the political gap and gained the trust of his sovereign (cf. Ayris 1993:130f.).

5.Famous for writing the moderate Tetrapolitan Confession (also known as the Swabian Confession or Strasbourg Confession) to establish a consistent Zwinglian theological platform

6.Letter CCXCIII dated Geneva, April 1552 (Bonnet 1857:330-333).

7.These articles later formed the basis for the more famous and enduring 39 Articles.

8.See the selection of catechisms and statements of faith ranging from Lutheran to Reformed, Anglican to Roman Catholic including some Anabaptist statements, for instance (Noll 1991).

9.'Neither Luther nor Calvin, nor any other person, was followed in our Reformation. The grand rule with our Reformers was the rule of Holy Scripture and primitive practice' (Lathbury 1859:57, 58). 
(1553-1603). Religious identity came in time with a new generation who knew nothing but the PB (and its catechism) and with little regard of its catholic past (Duffy 2005:593). Whatever winds of change blew into England from the Reformation on the continent, these met with the continual struggle to establish church and worship unconfused with Roman Catholic practices so that the Anglican identity would express Reformed doctrines uniquely to itself, approved by the sovereign and the people.

\section{A matter of authority}

The matter of authority in the Anglican community is important to understand. It ranges from being a matter of conscience, to sharing in religious identity based upon ecclesial and secular authority.

Harford (1912b:xiii) holds that authority was achieved by appeal to the dictates of conscience of individuals and community, as expressed in the text of the PB and may be opposed to dictates by authority (ecclesial or secular). This suggests that the $\mathrm{PB}$ was seen to be a translation of the understanding of Scripture issuing variously in its rites and rituals and embodied in its catechism and confession of faith in the form of the 39 Articles of Faith, inclusive of the creed. This authority of the PB was not taken in a final sense that there is no more to be said, but in terms of sufficiency.

Historically, the PB's esteem in the Anglican community is that according to the BCP (1662) it:

doth not contain in it anything contrary to the Word of God, or to sound Doctrine, or which a godly man may not with a good Conscience use and submit unto, or which is not fairly defensible against any that shall oppose the same. (p. viii)

Whilst doctrinal teaching may be distinguished in the BCP (Harford 1912a:289-290), its authority is within the context of liturgy, ranging supportively from parental to ecclesial levels. The intended distinction of doctrinal authority that accompanies the Apostle's Creed for instance, is that it is about truth as distinguished from teaching about duty (Harford 1912a:289).

For these reasons, the $\mathrm{BCP}$ is not distinguished from its doctrinal statements whether in the catechism (BCP 1662:289296) or in its 39 Articles of Religion (BCP 1662:611-628). It developed in a society in which every person was presumed to be Christian (Meyers 2006:492) and reflected that their theology was carried out and developed in the context of worship (Morris 2006:549). For these contextual reasons, an appeal to scripture does not feature prominently in relation to the $\mathrm{PB}$ and its contents, signifying its underlying prominence. This may also be the reason for the absence of scriptural references in the catechism, unlike the continental catechisms of the time. Preaching was generally a direct appeal to scripture; see sermons by Hooper, Simeon, Ryle and others.

Anglican doctrine, as distinguished from its preaching, should therefore be seen as being supplemented by statements from the PB (Harford 1912a:290). In particular, it must be pointed out that there should be caution exercised when reference is made to ' $[t]$ he Church...' or ' $[t]$ he whole Church teaches' (Harford 1912a:290) so as to distinguish what is denominationally unique and compatible to the Creeds but differ from contrary doctrines contravening them.

\section{Preparation for initiatory entrance into baptism and confirmation}

'A catechism has been defined as a manual of Christian doctrine, designed for a popular audience' (Turrel 2006:500), suggestive of a particular occasion and place. One may refer to Cyril of Jerusalem (c. 313-386) ${ }^{10}$, who in his exposition of the Creed of Jerusalem strongly associated with preparation for the initiation into the church through the rite of baptism (Hess 1997:314), a practice traced to the Middle Ages and according to Dearmer (1898:205), continued in the sense of initiation into Christian fellowship through the dual participation of baptism and confirmation. Baptism must not be divorced from Christian instruction however (Dickinson 1859:285), and the earnestness of this concludes with public affirmation of its vows at confirmation. Dearmer (1898:212-222) remarks on the seriousness and solemnity that were associated with these rites, impressing upon all participants the symbolic import of initiation signified by infant baptism, confirmation as the completed rite Christian initiation. Communion consequently followed the completed rite of baptism. For that reason, the PB emphasises teaching about the baptismal vow and the sacraments (Dearmer 1898:212). The administration of these 'rites and ceremonies' (BCP 1662:vii) are fixed forms in the PB establishing their universal significance and acceptance of recognition for their importance as rites.

Whilst the creeds express Christian catholic doctrine, the Anglican Catechism for instance, contains doctrine at an elementary level, but in general has the ecclesial purpose of preparation for entry into the ranks of Christian believers. The Reformation defined this further to include entry into a specified Protestant identity and more particularly, into churches representing particular expressions of reformed teaching. Continental Protestantism focussed on catechisms but the reformation of the Church of England took on a slightly different bent.

Amongst the laity, the direction of the Church for religious education was clear; a child had to be taught the Creed (doctrine), the Lord's Prayer (worship) and the Ten Commandments (conduct or morals), be instructed in the catechism, and hear sermons. This education was viewed as a shared responsibility between sponsors (godparents), parents and the minister of the congregation. Teaching culminated in the public catechising by the minister. With the rector's permission, the confirmees were presented for Confirmation by the bishop, after which they were welcome to partake of Holy Communion (Oberly 1896:4, 5).

10.See his 23 pastoral Catechetical Homilies (lectures) (Cyril 1839) and the introductory Protochatechesis (Cross 1977:45). 


\section{The place of the catechism in the various Books of Common Prayer}

The very first prayer book of the Edwardian Reformation $(1549)^{11}$, introduced on the day of Pentecost, included the first draft of the officially sanctioned catechism. Regarded as 'the last work of the Reformers in that reign' (Lathbury 1859:xi, quoting a Dr Randolph) the catechism was drawn up under the supervision of Cranmer. From its title, Confirmation, wherein is contained a Catechism for children, the same title followed in subsequent editions of 1552 and 1559 (Allen 1892:10). It was implied that children would be examined by means of the catechism and those who qualify would then be presented to the bishop for confirmation. The PB of 1604, with its expanded catechism, changed the title to The Order of Confirmation or laying on of hands upon children baptised and able to render an account of their faith according to the Catechism following. The final form was reached in the BCP 1662 on St. Bartholomew's Day, 24 August, in the title A Catechism, that is to say, an instruction to be learned of every person before he be brought to be confirmed by the Bishop (Allen 1892:10).

Allen (1892:16-17) shows that in the development of the various rubrics (liturgical rules included in the PB and usually in cursive) from 1552, the onus on teaching progressively extended the age of confirmation and was a forerunner of later Sunday Schools. Mere repetition was not regarded as being sufficient for confirmation by the bishop, as by 1662 the rubric allowed for the bishop to ask questions of confirmees not normally covered by the catechism. In practice, the bishop relied greatly upon the minister's recommendation. With the expansion of the Commonwealth, the word 'children' was substituted for 'persons', so as to include anyone the minister thought fit to be confirmed (Allen 1892:18). With this development, the examination of persons by a bishop was in effect, to some extent diminished.

A brief overview of the first catechism reveals that it was limited. It only extended to provide some explanation of the Lord's Prayer. Successful instruction supposedly produced knowledgeable children, who were brought to the bishop to be confirmed. This allowed them the privilege of receiving Holy Communion. Remarkably, Cranmer also associates the tedious pace of reform in England with the lack of religious education and profession of faith, which a catechism would clearly address (Dowling 1993:94).

The PB contained a rubric which required the curate of every parish to catechise the young and congregation on a Sunday or holy day once every six weeks (Cutts 1889:120-121). This instruction was in the form of catechising but the timing recommended was not popular with Puritans, as it took place in services and cut preaching time short (Lathbury 1859:159). To further direct catechising in the parishes and emphasise its importance, the 50th canon of 1663 contained penalties to

11.A remarkable achievement indeed, but not without its critics, who claimed for instance, retention of transubstantiation in its Eucharist rite and variously interspersed throughout the prayer book (Hall 1993:238, 243). How the Presence of deity was set forth at the Eucharist explained in the catechism, see Hall (1993:232) be imposed upon clergy who neglected this practice (Cutts 1889:121). This ranged from sharp rebuke, suspension for a second offence and excommunication for the third; a most serious matter.

\section{A general outline of the content and distinctives of the PBC}

Allen (1892) has noted:

The object of all religious teaching is not to lead children to repeat certain religious formulae, with more or less understanding, but to make them feel as a living reality the existence of their Father in heaven, their own personal relationship to Him, and the obligations which that relationship necessarily involves. (p. 12)

From its very inception, the catechism was designed to avoid abstract religious teaching, such as presenting God as removed from reality and not as a living person (Allen 1892:12).

In time, some difficulty with regards to words undergoing changes in meaning came about. By 1892, the inclusion of a bargaining element was imported into the word 'covenant' for instance, so that the blessings of baptism were not seen to precede it, but to follow baptism as a bargaining process (Allen 1892:14).

\section{Privilege to responsibility}

Historically, teaching the PB catechism in the Church of England has had the highest possible sanction, that of King Edward VI of England. In his injunction to the early catechisms he remarks that it is to be taught to the young so as to, amongst others, establish true religion and the right worship of God (Ketley 1844:493-494). Whereas it was seen to be part of the order of confirmation in the BCB 1549, in the BCP 1662 the catechism was published as a separate entry and so gained prominence as a key document for Anglican instruction (Lankshear \& Francis 1991:95). Ideally, this would ensure one generation after another continuing with the same faith in and worship of the same God and lead to express their devotion in daily life.

An analysis of the progression of the content of the PBC shows: 'It leads from privileges to responsibility' (Stevenson 1912:162). Stevenson (1912) illustrates this by referring to the fact that the catechism easily divides into five parts:

1. 'The privileges and profession of a Christian'

2. 'The Creed'

3. 'The Commandments'

4. 'The Lord's Prayer'

5. 'The Sacraments' (p. 162).

A more devotional take on its division is proposed by Dickinson (1859:286):

1. Christian privileges

2. Christian duties

3. Divine helps and the means of grace. 
Significant is the acceptance that the depth of meaning of the teaching of the catechism is only realised in later life when the child becomes an adult and in that sense is not to be regarded as being only for children (Stevenson 1912:162). But nor are children to accept the teachings simply because of the vows taken on their behalf by their sponsors (godparents), but because of the obligation they face themselves (Dickinson 1859:287). According to Stevenson (1912:162), the principles of truth and righteousness are timeless and translate for the individual into faith and duty and so withstand the test of time for each generation. Some of its phrases have been disputed; ' $[t]$ o order myself lowly and reverently to all my betters' has been interpreted as servility instead of simply seeing it as respect due to all in authority over that person (Stevenson 1912:162). This may have been the case for the author in 1912.

\section{A moderate question and answer format}

Turrel (2006:500) observes that although some catechisms followed the dialogue form, English catechisms generally followed the question and answer format of the continental Protestant patterns. Green (referred to in Turrel 2006:500) showed that there was a vast variety of catechisms doing the rounds in 1530-1740, although the basic text of many remained the $\mathrm{PB}$ catechism. A distinct impression is the moderate tone of most English catechisms. This is peculiarly so in dealing with matters of potential controversy. Harford (1912c:795) refers to 'doctrine of reserve'. He suggests that the discretion of 'parents and teachers, preachers and writers, have to consider, not merely what is true, but what is edifying'. This implies that although sensitive matters may be readily and wisely dealt with, not every occasion and immediate audience is suitable to convey such truths (Harford 1912c:795). Teaching about homosexuality, abortion, and election all need to be treated with caution, taking the audience and the speaker into consideration. Not every occasion is suitable to convey such truths.

\section{Relative to other catechisms}

It is the genius of the Reformation and its continued influence that a single catechism does not serve exclusively in the Protestant church. Most reformed churches accept the Heidelberg Catechism (HC), Belgic Confession of Faith, Synod of Dordt and see these as complementing one another, without a single one exhausting all that is contained in the Word of God. In a like manner, the PBC is complemented in a remarkable manner by its inclusion into the context of worship, comprising of a library of ceremonies, rites and symbols, supplemented for instance by specific doctrinal views expressed by the church calendar, 39 Articles, modes of baptism and rubrics guiding its ordered praxis.

\section{Contemporary overview}

Multiple Prayer Books in use in the Anglican community suggest that its historical approach to worship was never deemed to be static (Whalon 2006:551). Such multiplicity however, on the one hand resulted in new texts coming about to accommodate the PB culturally, but also the consequence of weakening of theology on the other (Gregory 2012:364). There is the opinion that its continuation may well have been that Christian religion maintains good order and well-being (Gregory 2012:329) with an inseparable blending of its ethics and economics within community (Gregory 2012:179). Additionally, PB (or its generic equivalent) rites and text were taken to represent a theological interpretation of biblical doctrines. Change to it was always regarded as a matter of serious reflection however, as it leads 'to make de facto a doctrinal statement' (Whalon 2006:555). In this case, the catechism and the 39 Articles of Religion would have to be in accord with such changes.

A dramatic change to the $\mathrm{PB}$ came about with the Alternative Service Book 1980 (ASB 1980) of the Church of England. Towards the end of the 1950s the Church of England sensed the need for revision, which included the catechism, and was undertaken by the Archbishops Commission, whose work was commended by the Convocations of Canterbury and York. Addressed was the modernising of language, enlarging the catechism through adding material on, for instance grace, Bible, Christian duty and hope (Lankshear \& Francis 1991:95). Absent from the publication of the ASB 1980 however, was the catechism. Nor was there any reference to it as 'Of teaching the young' was now covered by Canon B26, whilst Canon B27 refers to confirmation (Lankshear \& Francis 1991:95).

Other fundamental changes have taken place since 1980. For instance, The South African Anglican Prayer Book 1989 does not regard the biblical text but its authors to be inspired; in contrast, the Kenyan and Welsh catechisms regard scripture as inspired (Turrel 2006:508). New catechisms have come about with different intentions, such as merely outlining beliefs as platforms of departure without being conclusive or coming to grips with precise content, such as included in the American and New Zealand Prayer Books (Turrel 2006:505). New subjects have been added, such as stewardship, fasting and angels in the South African Anglican Prayer Book 1989. But the pendulum has also swung theologically. Some view the PB as a prayer to God, for it expounds his words, bringing about a tension between worship and belief ${ }^{12}$ in recreating the worshipping community through prayer and faith (Turrel 2006:556). This does little for an emphasis upon catechetical teaching. Confirmation in the New Zealand PB is regarded as a 'sacramental action', a discipleship which applies the catechism as a launch pad for conversation, the goal being that the confirmees will serve as Christian witnesses (Turrel 2006:507). Doctrinal development is not simply unification in faith, but is now replaced by the integrity of people worshiping and choosing to do so by means of liturgy (Morris 2006:545). This is a risk the church has to face (Morris 2006:550), affected by the further explicit tensions of culture and tradition in relation to scripture, in particular when it comes to interfaith dialogue (Turrel 2006:556). In formulating the PB of 1549 the reformers followed the reformational dictum of subjectivity

12.Application of the principal of lex orandi lex credenda [the law of prayer is the law of belief]. 
to the authority of scripture. At present, the subjectivity seems to be that 'Anglicans do their theology in the context of worship' (Morris 2006:549) within the wider context of its missio dei as '[o]ur mission and ministry to God's creation is at the core of life in the church' (Morris 2006:550) and not necessarily confined to texts.

Whalon (2006:551) is of the opinion that though neither drastic nor minor they will affect the enduring use of the $\mathrm{PB}$, because Anglican worship has never been a static tradition (Whalon 2006:552). On the other end of the spectrum, Kraus (2006:541) maintains that the unvarying form of the words comprising the liturgy breed necessary familiarity, supposedly allowing continued focus on prayer and meditation. Such mindless repetition is suggestive of it being a platform to higher exaltation and one can only conclude that even with change, familiarity may be regained.

From the aforementioned context, the question is therefore whether the catechism has reached its sell-by-date or whether it still has a role to play in the Anglican Communion? I submit that the same questions may be applied to any catechism, not least the PBC.

How do other catechisms and confessions face this modern critical onslaught? Heron (1986:1) does not question the theological integrity of the Westminster Confession, but its theological adequacy and whether it continues its role as relevant of its teaching. On the other hand, Van't Spijker (2009) expresses in a compendium the content of the catechism for its enduring historical and present relevance, in particular for its centrality upon Christ.

\section{Establishing a 'sell-by date'}

Sober reflection of the previous must surely conclude with at least the following:

1. The compendium comprising the BCP since its inception was defined, formulated and honed in the spirit of reformed theology. Concluded by 1662, it served as a unique treasure for the Church of England, ensuring its Anglican and theological identity to the present.

2. Its catechism has always been found in the context of worship, sustained by the theology of the compendium as a whole to the benefit of the successive generations of baptised members of the Church of England.

3. The theological integrity of the BCP and its catechism is never the issue, although the intentions may differ from culture to culture and order their application or lack of, such as the catechism in some prayer books.

Whilst points 1 and 2 reflect the historical inheritance that accompanies the PB, point 3 secures the integrity of Anglican worshipers but includes a desire for some leeway to meet the present challenges facing the Anglican Communion. This needs some comment before concluding on a sell-by date.

Chang (2000) develops the thesis of his book engaging unbelief along the lines of facing a historical story in juxtaposition with the present story (read Western story). But the helpful insight that he brings in the first place, in my opinion, is the need to grapple with two languages; that of the seminary and that of a world in a postmodern epoch (Chang 2000:172). This includes embracing the voices from beyond the West to include on the one hand that of Africa, Asia, but also that which shout so loudly through Hollywood and the Internet, physical science and biology, ethics and philosophy and so on. The days of marginalising these voices to the periphery of the church are over. Indeed, some of the most crucial questions emanate from these voices. Christianity must address the whole of living and reality.

Secondly, Chang (2000:144) wants to distinguish between what may be regarded as truth and the power to effect change. He insightfully does not equate the maxim of 2 Corinthians 10 of 'taking every thought captive' with power that brings about change. Christ alone possesses that power. This leads to some reflection. In the matter of catechisms, these largely confine themselves to 'ecclesial' truths, with the implicit application that religious truths of the Bible belong to and are effective mainly in the church.

Extending the thought of authority reveals the PBC is mainly confined to an insular mono-cultural understanding of catechetical questions and answers deliberately framed to serve within the Church of England or Anglican ecclesial laager. In South Africa, Protestant denominations were, and still are, notorious for their exclusivity; not only in doctrine, but also in selective ecclesial community involvement, somewhat addressed by the Belhar Confession of 1982, said to be the consequence of a 'moment of truth' (Naudé 2010:91). In spite of Christians sharing in sensus divinitatis, sadly the expression of their faith in the form of catechisms and confessions in South Africa did not prove to be sufficient to address the parasitical apartheid system which appended to and wove itself into the religious fabric of white South African faith.

Venturing beyond the mono-culture of one Christian faith to another is to meet with Christian pluralism and meeting with the challenges of their questions and grappling with their answers. An even wider horizon extends beyond Christian circles to meet with complete indifference to religion (Christian or not), secular forms of faith, indifference to mores and justice not relativised and more.

In addition to the previous, I would like to suggest that the catechism needs to clearly acknowledge that there is truth outside of the Church ${ }^{13}$. This means that the Church does not have authority to pronounce indiscriminately upon non-ecclesial matters. It is the Bible that needs to be consulted and cautiously applied for fear of wrong exegesis and hermeneutics. This is no excuse not to venture beyond the traditional ecclesial boundaries, only a plea for extreme humility and caution. Necessary questions and answers for its community are needed to prepare the Church community

13.Reminiscent of Karl Rahner's fulfilment paradigm (1973). This was expanded upon with some tongue-in-cheek banter by Peter Kreeft (1996). 
for its contact with the book of nature day by day. I would submit that the right relationship with physical science, philosophy, economics, psychology, and so on should be regarded as suitable tools for aiding that complex engagement. Conscientious tensions; distinguishing weekday ethics with that promoted on Sundays in gospel preaching pulpits, doing science in polarised fashions that vaguely resembles the scriptural model advocated from the pulpit and theologians may well be addressed to some extent in this manner.

Further limitations of the catechism have to be addressed. Matters such as the integrity of aesthetic appreciation, concern for ecology of the natural world, regardless of particular allegiance to some religion are matters critical for continued sustaining of humankind and without which human life would have been so much the poorer (Cottingham 2009:158ff.). In short it is a matter of addressing the multifaceted fullness of reality, for Christians are increasingly aware of living beyond the historical confines of that which was defined as 'church'.

Catechisms foster a theistic understanding for this world, in Kenny's (2004) opinion, not because God is:

part of any of the explanatory series which he is invoked to account for - he is first mover unmoved, he is first cause only by analogy - the vocabulary and predicates of the different explanatory series are not applicable to him in any literal sense. (p. 14) $)^{14}$

Revelation does not deal with understanding so much as with explanation (Kenny 2004:14), so that the Bible story or God may not be presented as an alternate catechetical explanatory hypothesis. If it is, then God enters the fray and is relegated to some unexplained gaps in scientific theory to be imbibed by church members. But the catechism must also be clear in its formulations; claims to further scientific light from some pseudo-science claimed to be based upon the Bible as explanation (Chamberlain 2011; Cottingham 2009:167) must be resisted, for the concept of God is not of personal choice or of some lobby, but is based on acquisition of knowledge (revelation) being outside of time (Kenny 2004:80). The same applies to moral purity. Catechisms are not generally regarded as explanatory of good moral conduct in the world outside of the church community, taking the unique dynamics of the wider world into consideration.

In the light of the aforementioned, I suggest that expanding the present Anglican Catechism be reviewed or better, consideration be given to framing an additional catechism, the status of which may be determined in time ${ }^{15}$.

14.I am grateful to John Cottingham for his references to Anthony Kenny's (2004) The unknown god (read Unmoved Mover), which prompted me to explore the latter's philosophical approach in support of agnosticism.

15.This suggestion clearly needs to be expanded upon. The internal dimension of accepted communal belief, here represented by a catechism, must ever be seen as affirming historic scriptural truths, but its address goes beyond that of the community of the faithful. Of necessity, it needs to expand this truth framework to address issues of the day that infiltrate the church community inside and outside of address issues of the day that infiltrate the church community inside and outside of
the church. By its very nature this approach will then be dynamic and cannot accept the church. By its very natur
any catechism as static.

\section{Conclusion}

It is not my belief that catechisms, least of all the Anglican Catechism, have reached their sell-by date. Christians live as the organism through which Christ acts in the world (Chamberlain 2011:154). Jesus called his new people to serve as witnesses within the church and the world simultaneously; our children and members need, more than ever, to be equipped to do so. The reality is that children must be instructed in Christian truth, incorporating the whole of reality and grounded in a living faith in Jesus Christ. This will probably necessitate additional questions and answers to be framed in addition to those in the catechism, so that Sunday living becomes part and parcel of seven day living in a hundred and sixty eight hour week. A second catechism is not discounted. For an Anglican however, the context of living remains that of worship of the God of the Bible, extended to include all of life.

\section{Acknowledgements Competing interests}

The author declares that he has no financial or personal relationship(s) that may have inappropriately influenced him in writing this article.

\section{References}

Allen, A.J.C., 1892, The church Catechism: Its history and contents. A manual for teachers and students, Longmans \& Green, London.

Ayris, P., 1993, 'God's viceregent and Christ's vicar: The relationshop between the crown and the archbishopric of Canterbury 1533-53', in P. Ayris \& D. Selwyn (eds.), Thomas Cranmer, churchman and scholar, pp. 115-156, The Boydell Press, Woodbridge.

Bonnet J., 1857, Letters of John Calvin, compiled from the original manuscripts and edited with historical notes, translated from the original Latin and French, Thomas Constable, Edinburgh.

Chamberlain, P., 2011, Why people don't believe: Confronting seven challenges to Christian faith, Baker Books, Grand Rapids.

Chang, C., 2000, Engaging unbelief: A captivating strategy from Augustine and Aquinas, InterVarsity Press, Downers Grove.

Cottingham, J., 2009, Why believe?, Continuum, London.

Cross, F.L. \& Livingstone, E.A. (eds.), 1974, The Oxford dictionary of the Christian Church, 2nd edn., Oxford University Press, Oxford.

Cross, F.L. (ed.), 1977, Lectures on the Christian sacraments: The protochatechesis and the five mystagogicla chatecheses, St. Vladimir's Seminary Press, New York. (Popular Patristic Series).

Cutts, E.L., 1889, A dictionary of the Church of England, published under the direction of the Tract Committee, Society for Promoting Christian Knowledge, London.

Cyril of Jerusalem, 1839, The catechetical lectures of S. Cyril, archbishop of Jerusalem, translated with notes and indices, John Henry Parker, London.

Dearmer, P., 1898, Religious pamphlets, with an introduction and notes, Kegan Paul, Trench, Trübner \& Co, London.

Dickinson, H.H., 1859, Lectures on the Book of Common Prayer, Hodges, Smith, \& Co, Dublin.

Dowling, M., 1993, 'Cranmer as humanist reformer', in P. Ayris \& D. Selwyn (eds.) Thomas Cranmer, churchman and scholar, pp. 89-114, The Boydell Press, Woodbridge.

Duffy, E., 2005, The stripping of the altars: Traditional religion in England 1400-1580, Yale University Press, New Haven and London.

Eland, E.H., 1896, The layman's introduction to the Book of Common Prayer: Being a short history of its development, Longmans \& Green, London.

Gregory, B.S., 2012, The unintended Reformation: How a religious revolution secularized society, The Belknap Press of Harvard University Press, Cambridge. http://dx.doi.org/10.4159/harvard.9780674062580

Hall, B., 1993, 'Cranmer, the Eucharist and the foreign divines', in P. Ayris \& D. Selwyn (eds.), Thomas Cranmer, churchman and scholar, pp. 217-258, The Boydell Press, Woodbridge.

Harford, G., 1912a, 'Doctrine in The Prayer Book Dictionary', in G. Harford \& M. Stevenson (eds.), The Prayer Book Dictionary, pp. 289-290, Sir Isaac Pitman \& Sons, London. 
Harford, G., 1912b, 'Introduction', in G. Harford \& M. Stevenson (eds.), The Prayer Book Dictionary, pp. xi-xiv, Sir Isaac Pitman \& Sons, London.

Harford, G., 1912c 'Strong matters', in G. Harford \& M. Stevenson (eds.), The Prayer Book Dictionary, pp. 795, Sir Isaac Pitman \& Sons, London.

Hefling, C., 2006, 'Introduction: Anglicans and Common Prayer', in C. Hefling \& C. Shattuck (eds.), The Oxford guide to the Book of Common Prayer: A worldwide survey, pp. 1-6, Oxford University Press, New York.

Heron, A.I.C. (ed.), 1986, The Westminster confession in the church today: Papers prepared for the Church of Scotland panel on doctrine, The Saint Andrew Press, Edinburgh.

Hess, H., 1997, 'Soteriological motifs in the Catechetical lectures of St. Cyril of Jerusalem', in Studia Patristica, vol. XXXII, pp. 314-319, Peeters Publishers, Louvain.

Jeanes, G., 2006, 'Cranmer and Common Prayer', in C. Hefling \& C. Shattuck (eds.) The Oxford guide to the Book of Common Prayer: A worldwide survey, pp. 21-38, Oxford University Press, New York.

Kenny, A., 2004, The unknown god, Continuum International Publishing, London.

Ketley, J., 1844, The two liturgies, A.D. 1549 and A.D. 1552: With other documents se forth by authority in the reign of King Edward VI. The order of communion, 1548. The Primer, 1553. The catechism and articles, 1553. Catechismus brevis, 1553, edited for The Parker Society, The University Press, Cambridge.

Kraus, D., 2006, 'The Book of Common Prayer and technology', in C. Hefling \& C. Shattuck (eds.), The Oxford guide to the Book of Common Prayer: A worldwide survey, pp. 541-544, Oxford University Press, New York.

Kreeft, P., 1996, Ecumenical Jihad: Ecumenism and the culture war, Ignatius Press, San Francisco.

Lankshear, D.W. \& Francis, L.J., 1991, 'The use of the revised catechism in Anglican Churches', British Journal of Religious Education 13(2) 95-100. http://dx.doi. Churches', British Journal of Religio
org/10.1080/0141620900130204

Lathbury, T., 1859, A history of the Book of Common Prayer and other books of authority: An attempt to ascertain how the rubrics and canons have been understood and observed from the Reformation to the accession of George III: Also an account of the state of religions and religious parties in England from 1640 to 1660,2 nd edn., John Henry \& James Parker, Oxford \& London.
Liverpool, F.J., 1912, 'Preface', in G. Harford \& M. Stevenson (eds.), The Prayer Book Dictionary, pp. vii-viii, Sir Isaac Pitman \& Sons, London.

Luckock, H.M., 1882, Studies in the history of the Book of Common Prayer, 2nd edn., Rivington, London.

Meyers, R.A., 2006, 'Rites of initiation', in C. Hefling \& C. Shattuck (eds.), The Oxford guide to the Book of Common Prayer: A worldwide survey, pp. 484-499, Oxford University Press, New York.

Morris, C.L., 2006, 'The Prayer Book in Cyberspace', in C. Hefling \& C. Shattuck (eds.) The Oxford guide to the Book of Common Prayer: A worldwide survey, pp. 545550, Oxford University Press, New York.

Naudé, P.J., 2010, Neither calendar nor clock: Perspectives on the Belhar Confession, William B. Eerdmans Publishing, Grand Rapids.

Noll, M.A. (ed.), 1991, Confessions and catechisms of the Reformation, Baker Book House, Grand Rapids.

Oberly, H.H., 1896, Systematic catechizing: Directions and suggestions for catechists and teachers. Hand-book to lessons on the Prayer Book Catechism, James Pott, New York.

Rahner, K., 1973, Belief today, Sheed \& Ward, London.

Stevenson, 1912, 'Catechism, the church', in G. Harford \& M. Stevenson (eds.), The Prayer Book Dictionary, pp. 160-163, Sir Isaac Pitman \& Sons, London.

The Book of Common Prayer and administration of the sacraments and other rites and ceremonies of the church according to the use of the Church of England together with the psalter or psalms of David pointed as they are to be sung or said in churches and the form or manner of making ordaining and consecrating bishops priests and deacons, (BCP 1662), Cambridge University Press, Cambridge.

Turrel, J.F., 2006, 'Catechism', in C. Hefling \& C. Shattuck (eds.), The Oxford guide to the Book of Common Prayer: A worldwide survey, pp. 500-508, Oxford University Press, New York.

Van't Spijker, W. (ed.), 2009, The church's book of comfort, transl. Gerrit Bilkes, Reformation Heritage Books, Grand Rapids.

Whalon, P.W., 2006, 'The future of common prayer', in C. Hefling \& C. Shattuck (eds.) The Oxford guide to the Book of Common Prayer: A worldwide survey, pp. 551557, Oxford University Press, New York. 